Philippe on the Seine. Jouffroy died in the Invalides on August 7, 1832. His statuo was orected at Besançon in 1884 .

\section{Bronze Age Implements}

A Research committee of the British Association, first appointed twenty years ago at the Birmingham meeting, to report on the distribution of bronzo ago implements, reported at the Leicester meeting that its labours, so far as England and Wales are con. cerned, are now completed. With a fow insignificant exceptions, all the specimens in museums and private collections in England and Wales, in the Isle of Man and in the Channel Islands, a majority of the specimens in Scotland, a considerable number of those in Ireland, and early specimens from the Museum in Copenhagen have been drawn, measured and described in an illustrated card catalogue, which is deposited, and is available for consultation, in the rooms of the Society of Antiquaries, London. The most important exceptions in the list of specimens are those of foreign origin in the British Museum, the Ashmolean and the museum at York. The original intention of the committee when it was first appointed was, by international co-operation, to extend the catalogue to cover the whole of Furope and the adjacent lands. The question was raised at the meeting of the Association Frunçaise in July 1914, but came to nothing owing to the War; while a further attempt to secure international action made at the Prehistoric Congress in 1932, has, as yet, produced no result.

\section{Wild Bird Sanctuaries}

A commitTeE has been formed in Manchester, with the Earl of Stamford as chairman, to perpetuate the name of the late T. A. Coward, an honorary keeper of the vertebrate collection at Manchester Muscum and an eminent ornithologist, by purchasing two wild birds' sanctuaries in Cheshire. It has also been decided by the Lancashire and Cheshire Fauna Committee to dedicate Part 2 of its "Check List of the Fauna of Lancashire and Cheshire" to the late Mr. Coward; the first part, published in 1930, was dedicated to the memory of Mr. Linnaeus Greening. Of tho two memorial sanctuaries, Cotterill's Clough, a hanging wood on the River Bolling within sight of Coward's home at Bowdon, has yet to be purchased, though most of the second, the reed beds and woodland at Marbury Mere, have been acquired. At the former, Coward recorded the grasshopper-warbler in 1898 , and thirty-two nesting species were recently listed, while at Marbury the bittern is a frequent winter visitor, the night heron has been recorded, and A. W. Boyd recorded 23 black terns on August 18, 1930 (British Birds, 25, 276, 297). The usefulness of certain wild bird sanctuaries for ornithological records and observations is amply demonstrated by those of the Norfolk Naturalists' Trust, and tho reports of the Committee on Bird Sanctuaries in the Royal Parks, which have recorded some sixty nesting species in Richmond Park. Facilities for observation on nesting waterfowl at the late Lord Grey's private bird sanctuary have produced valuable information ( $N a t$. ural History Magazine, Oct. 1930) and the recently acquired sanctuary at Dungeness will, it is hoped, preserve one of the fow remaining nosting sites of tho Kentish plover (Egialitis cantiana). The sanctuary at Liverpool Cathedral has proved valuable in observations on movements of eity birds (NATURF, Aug. 5, p. 199).

\section{Right- and Left-Handed Spirals in Gastropods}

A correspondent has raised the question as to whether there is any explanation for the fact that spiral shells of present-day marine gastropods wind in the opposite direction to similar shells found in the Crag formation of East Anglia. The first point is that only certain species of fossil shells wind in this manner, and although it is usual for present. day gastropods to be dextral, that is to say, they wind in the ordinary clock-wise spiral, there are certain genera which always wind in the opposite direction and are sinistral; also in species which are usually dextral, there aro frequently sinistral varieties. The well-known fossil shell Fusus contrarius from the Red Crag is so common that it has given rise to the idea that all fossil shells of this kind are sinistral, but there are a largo number of fossil gastropods which are normally dextral and, to take but one example, the common 'Buckie', Buccinum undatum, closely related to Fusus, sometimes is sinistral although normally dextral. Other common recent gastropods which are known to have sinistral varieties are the edible snail, Helix pomatia, and the common fresh-water snail, Limnoa peregra. A good deal of work has been done, and is still going on, on the breeding of the last-named mollusc in order to find out the reason for these sinistral varieties (Diver, Buycott and others), the conclusion boing that the general organisation of the germ cell determines whether the animal is to bo dextral or sinistral, the factors for right-handedness or left-handedness being in the chromosomes and inherited in special ways. A sinistral individual may have an entirely sinistral brood or it may have an entirely dextral brood or a mixture, the broods from these varying to a large degree. Besides truly sinistral shells which also have a sinistral animal, there are species with a sinistral shell and dextral animal. It is practically certain, however, that the fossil Fusus must have been wholly sinistral both in shell and animal.

\section{A Triple Rainbow}

Mr. R. C. T. Evans, of 10 Eddington Lane, Horne Bay, has forwarded a description of an unusual rainbow seen by him at Herne Bay that differs from any of those described in recent numbers of NATURE, in that it made a considerable angle with the ordinary primary and secondary bows, implying that the sur was not at the centre of curvature of the unusual bow. The phenomenon was seen at $18 \mathrm{~h}$. $20 \mathrm{~m}$. G.M.T., prosumably on a date in the third weck of August; it was visible for about fivo minutes, the secondary bow for only about three minutes, while the primary bow lasted much longer. The tide was low at the 